\title{
Commentary: $T$ cells regulate lung transplant rejection in mice and men
}

\author{
Jason M. Gauthier, MD, ${ }^{a}$ Wenjun Li, MD, ${ }^{a}$ and Daniel Kreisel, MD, PhD ${ }^{\mathrm{a}, \mathrm{b}}$
}

\footnotetext{
From the Division of Cardiothoracic Surgery, Departments of a Surgery and ${ }^{\mathrm{b}}$ Pathology and Immunology, Washington University in Saint Louis School of Medicine, St Louis, Mo.

Disclosures: D.K. is on the scientific advisory board of Compass Therapeutics and receives research support from Compass Therapeutics. All other authors have nothing to disclose with regard to commercial support

Received for publication Jan 25, 2019; accepted for publication Jan 28, 2019; available ahead of print Feb 26, 2019.

Address for reprints: Daniel Kreisel, MD, PhD, Washington University School of Medicine, Campus Box 8234, 660 S Euclid Ave, St Louis, MO 63110 (E-mail: kreiseld@wustl.edu).

J Thorac Cardiovasc Surg 2019;157:2538-9

$0022-5223 / \$ 0.00$

Published by Elsevier Inc. on behalf of The American Association for Thoracic Surgery https://doi.org/10.1016/j.jtcvs.2019.01.101
}

Since the advent of lung transplantation, chronic lung allograft dysfunction (CLAD) has been the number one cause of long-term mortality. ${ }^{1}$ A subset of $\mathrm{T}$ cells, known as regulatory T cells (Tregs), have been shown to suppress inflammatory responses after organ transplantation. Much of what is known about the role of Tregs in suppressing alloimmune responses has come from experimental studies of kidney, heart, pancreatic islet, liver, and bone marrow transplantation. On the basis of these findings, 2 phase I clinical trials in which adoptively transferred Tregs were administered after kidney transplantation have been completed. ${ }^{2,3}$ Such clinical progress has yet to be made for lung transplantation, however, because the role of Tregs in this setting is just beginning to emerge.

In 2017, Abrams and colleagues ${ }^{4}$ performed a series of canine lung transplants mismatched for minor histocompatibility antigens without immunosuppression and infused recipient-derived, in vitro major histocompatibility antigen-primed Tregs cells that were selected on the basis of their expression of $\mathrm{CD} 25$, a putative surface marker of Tregs, shortly after graft reperfusion. They found that allograft survival correlated with the in vitro suppressive capacity of the infused Tregs. Shortly thereafter, Warnecke's group at Hannover Medical School, ${ }^{5}$ one of the most distinguished lung transplant centers in the world, reported that an increased frequency of peripheral Tregs shortly after lung transplantation in human patients is associated with protection from CLAD. To study these findings, this group recently established an elegant model of transplant atherosclerosis in humanized mice, whereby peripheral leukocytes from a human lung recipient are transferred into an immunodeficient mouse that receives a segment of a pericardiophrenic artery from the human lung donor. With this model, the Hannover researchers have shown that transfer of recipient-derived leukocyte preparations rich in Tregs abrogates atherosclerosis of the human donor arterial segments. ${ }^{6}$

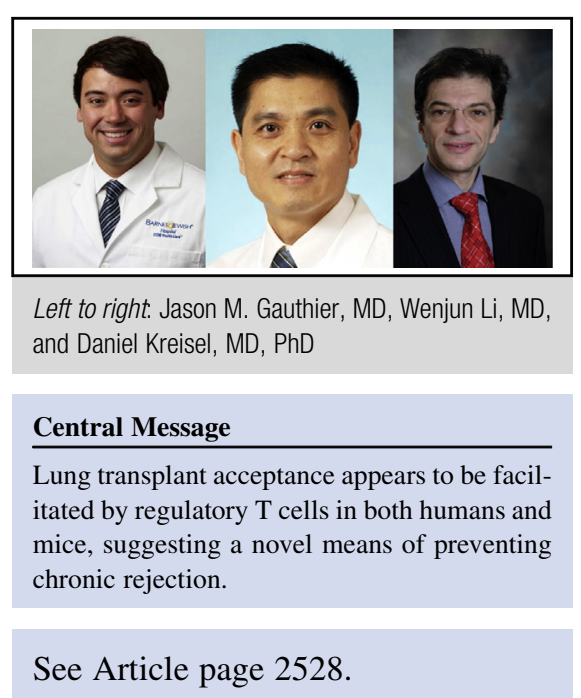

In this issue of the Journal, Siemeni and colleagues ${ }^{7}$ from the Hannover lung transplant group extend these findings to show that leukocyte preparations taken from patients who ultimately develop CLAD results in more severe atherosclerosis of the transplanted arterial segment in the humanized mice. Perhaps more importantly, they have found that adoptive transfer of Treg-enriched leukocyte preparations is able to abrogate this process. In our own laboratory, we have observed that lymphoid follicles rich in Tregs are abundant in both human and mouse lung transplant grafts that are accepted long term. ${ }^{8}$ When we selectively deplete lungresident Tregs from tolerant murine pulmonary allografts, they develop antibody-mediated rejection, associated with small airway destruction reminiscent of CLAD in human recipients. ${ }^{9}$ These observations have suggested that the immune tolerance conveyed by Tregs occurs locally within allografts, which is distinctly different from other solid-organ transplants, in which immune regulation occurs in peripheral lymphoid tissues. Our findings reinforce those of Siemeni and colleagues ${ }^{7}$ to suggest that deleterious alloimmune responses after lung transplantation are suppressed by Tregs and set the stage for tolerance. Novel strategies that enrich Tregs after human lung transplantation are called for, and we hope these recent findings will lead to clinical trials in the near future.

\section{References}

1. Christie JD, Edwards LB, Kucheryavaya AY, Aurora P, Dobbels F, Kirk R, et al. The registry of the International Society for Heart and Lung Transplantation: 
twenty-seventh official adult lung and heart-lung transplant report-2010. J Heart Lung Transplant. 2010;29:1104-18.

2. Chandran S, Tang Q, Sarwal M, Laszik ZG, Putnam AL, Lee K, et al. Polyclonal regulatory $\mathrm{T}$ cell therapy for control of inflammation in kidney transplants. Am J Transplant. 2017; 17:2945-54.

3. Mathew JM, H-Voss J, LeFever A, Konieczna I, Stratton C, He J, et al. A phase I clinical trial with ex vivo expanded recipient regulatory t cells in living donor kidney transplants. Sci Rep. 2018;8:7428.

4. Abrams KV, Hwang B, Nash RA, Georges GE, Lamm W, Storer B, et al. The use of ex vivo generated regulatory T-cell preparations in a canine lung allograft model. Transplantation. 2017;101:e326-7.

5. Salman J, Ius F, Knoefel AK, Sommer W, Siemeni T, Kuehn C, et al. Association of higher CD4 + CD25high CD127low, FoxP3+, and IL-2 + T cell frequencies early after lung transplantation with less chronic lung allograft dysfunction at two years. Am J Transplant. 2017;17:1637-48.
6. Siemeni T, Knöfel AK, Madrahimov N, Sommer W, Avsar M, Salman J, et al In vivo development of transplant arteriosclerosis in humanized mice reflects alloantigen recognition and peripheral Treg phenotype of lung transplant recipients. Am J Transplant. 2016;16:3150-62.

7. Siemeni T, Knöfel AK, Ius F, Sommer W, Salman J, Böthig D, et al. Transplant arteriosclerosis in humanized mice reflects chronic lung allograft dysfunction and is controlled by regulatory T cells. J Thorac Cardiovasc Surg. 2019;157: 2528-37.

8. Li W, Bribriesco AC, Nava RG, Brescia AA, Ibricevic A, Spahn JH, et al. Lung transplant acceptance is facilitated by early events in the graft and is associated with lymphoid neogenesis. Mucosal Immunol. 2012;5:544-54.

9. Li W, Gauthier JM, Higashikubo R, Hsiao HM, Tanaka S, Vuong L, et al. Bronchus-associated lymphoid tissue-resident Foxp3 $+\mathrm{T}$ lymphocytes prevent antibody-mediated lung rejection. J Clin Invest. 2019;129: 556-68. 